IZA DP No. 10041

Competitive Strategy, Performance Appraisal and Firm Results

Alberto Bayo-Moriones

Jose E. Galdon-Sanchez

Sara Martinez-de-Morentin

July 2016 


\title{
Competitive Strategy, Performance Appraisal and Firm Results
}

\author{
Alberto Bayo-Moriones \\ Universidad Publica de Navarra \\ Jose E. Galdon-Sanchez \\ Universidad Publica de Navarra \\ and IZA \\ Sara Martinez-de-Morentin \\ Universidad Publica de Navarra \\ Discussion Paper No. 10041 \\ July 2016 \\ IZA \\ P.O. Box 7240 \\ 53072 Bonn \\ Germany \\ Phone: +49-228-3894-0 \\ Fax: +49-228-3894-180 \\ E-mail: iza@iza.org
}

\begin{abstract}
Any opinions expressed here are those of the author(s) and not those of IZA. Research published in this series may include views on policy, but the institute itself takes no institutional policy positions. The IZA research network is committed to the IZA Guiding Principles of Research Integrity.

The Institute for the Study of Labor (IZA) in Bonn is a local and virtual international research center and a place of communication between science, politics and business. IZA is an independent nonprofit organization supported by Deutsche Post Foundation. The center is associated with the University of Bonn and offers a stimulating research environment through its international network, workshops and conferences, data service, project support, research visits and doctoral program. IZA engages in (i) original and internationally competitive research in all fields of labor economics, (ii) development of policy concepts, and (iii) dissemination of research results and concepts to the interested public.
\end{abstract}

IZA Discussion Papers often represent preliminary work and are circulated to encourage discussion. Citation of such a paper should account for its provisional character. A revised version may be available directly from the author. 


\begin{abstract}

\section{Competitive Strategy, Performance Appraisal and Firm Results}

In this study, we address the relationship between performance appraisal and competitive strategy, as well as the impact of this relationship on firm performance. The results indicate that the adoption of developmental performance appraisal and the use of administrative performance appraisal are higher among firms that pursue differentiation strategies compared to those competing on costs. Regarding firm performance, the interaction between a developmental appraisal system and a quality strategy displays higher return on equity and sales per employee. Those firms that combine a focus on innovation with administrative performance appraisal also enjoy higher performance. Finally, when the firm competes on the basis of cost reduction, the use of administrative appraisal increases the sales per employee.
\end{abstract}

JEL Classification: M12, M52

Keywords: performance appraisal, competitive strategy, firm performance, developmental appraisal, administrative appraisal

Corresponding author:

Jose E. Galdon-Sanchez

Department of Economics

Universidad Publica de Navarra

Campus de Arrosadia

Pamplona 31006

Spain

E-mail: jose.galdon@unavarra.es 


\section{Introduction}

The monitoring and evaluation of workers is an issue of relevance in many organizations. However, there are significant differences in the way employers approach their appraisal needs. In some organizations, monitoring is an informal activity (see Brown and Heywood, 2005). In others, a formal process of performance appraisal is established. Among its multiple functions, formal performance appraisal is used to communicate organizational objectives to workers (see Baron and Kreps, 1999). It can also serve to evaluate if workers' behaviour and actions are congruent with the strategic goals of the firm. Through the process of evaluation, the culture, norms and purposes of the firm can be translated to the employees. Hence, performance appraisal can be used as an instrument to inform workers about the firm's competitive strategy, so they can align their work with the strategic objectives of the organization (see Macduffie, 1995).

These ideas highlight the existence of a valuable connection between the use of formal performance appraisal and the implementation of the firm's competitive strategy. In fact, researchers have claimed the importance of linking the design of human resource management (HRM) systems with the firm's competitive strategy for many years (see, for example, Schuler and Jackson, 1987). Previous work has supported this claim, showing that the impact of performance appraisal on firm performance is contingent on the business strategy (see Youndt et al., 1996).

There are some studies that link HRM systems to competitive strategy and firm performance, mentioning the use of formal performance appraisal (see Schuler and Jackson, 1987; Arthur, 1992; Huselid, 1995; Snell and Youndt, 1995; Delery and Doty, 1996; Youndt et al., 1996; Sanz-Valle et al., 1999; Ding and Akhtar, 2001; Michie and Sheenan, 2005; Neal et al., 2005; and Zhang and Li, 2009; among others). In general, 
the existent studies consider the use of performance appraisal as one of the elements that may compound HRM systems. However, to our knowledge, none of them takes into account how the specific design of the practice matches competitive strategy, and how this match affects firm performance.

On the one hand, the design of the practice is of high relevance since performance evaluation is a multidimensional process and its design may differ significantly among employers. According to Brown and Heywood (2005), the employer has to decide not only whether it is worth adopting a system of performance appraisal, but also how this system should be shaped in order to obtain positive returns. As Baron and Kreps (1999) point out, the appropriateness of a system of performance appraisal depends on the characteristics of the organization and the HRM system adopted by the employer. On the other hand, researchers should bear in mind that the ultimate goal of performance management is to improve firm's performance (see Kuvaas et al., 2014). This omission in the literature is particularly relevant from the practitioner's point of view. DeNisi and Pritchard (2006) make reference to it when they describe the shortcomings of the existent literature on appraisal. According to these authors, a significant amount of research on performance appraisal has lost its main focus, neglecting the practical implications of its adoption and, in particular, its impact on performance.

In light of the gap in the literature, our aim in this paper is to analyse the relationship between the competitive strategy pursued by a firm, the type of performance appraisal adopted and firm performance. In particular, we try to answer the following questions. First, we examine how the competitive strategy pursued by the organization influences the configuration of performance appraisal. In order to do so, we classify performance appraisal systems in two categories: developmental behaviour- 
oriented, and administrative results-oriented. Regarding competitive strategy, we differentiate between firms focusing on cost reduction, quality enhancement, and innovation.

Second, we analyse the relationship between competitive strategy, performance appraisal and firm performance. In order to do so, we use the return of equity (ROE) and the sales per employee as measures of performance. The analysis is based on a unique data set that includes information about 258 Spanish firms in the manufacturing and services sectors. For each firm, two questionnaires were completed. The first one was addressed to the $\mathrm{CEO}$ and included questions about strategy, organizational design and performance. The second one was sent to the senior human resource manager and requested information about HRM and work organization aspects.

Our results show that those firms focusing on innovation and quality strategies are more likely to implement developmental performance appraisal compared to those firms competing on costs. In addition, innovation and quality firms make a greater use of administrative results-oriented performance appraisal. Regarding firm performance, the adoption of performance appraisal based on development jointly with a quality strategy exerts a positive influence on the ROE and the sales per employee. A larger ROE is also related to the combination between an administrative performance appraisal system and an innovation focus. Finally, when the strategy is based on cost reduction, the use of administrative appraisal increases the sales per employee.

The remainder of the paper is organized as follows. In Section 2, we describe the two main approaches adopted by organizations when designing performance appraisal. Section 3 provides an overview of the theoretical insights regarding the relationship between performance appraisal, competitive strategy and firm performance. This is 
followed by a section on the methodology used in our empirical analysis. Finally, the findings of the study are described and discussed, and our main conclusions presented.

\section{The design of performance appraisal}

The design of a performance appraisal system is a complex process due to the multiple aspects involved and the varying interests in evaluation outcomes existing among different agents. A system of appraisal is organized along several dimensions, all of which should be carefully considered. Among these dimensions, we can mention the person who conducts the evaluation, the criteria used to evaluate performance, the periodicity of appraisal, or the purposes of the practice. Hence, the employer has to decide not only if it is worth adopting a formal system of performance appraisal, but also how this system will be shaped in order to obtain returns from its use (see Baron and Kreps, 1999).

When thinking about the design of performance appraisal, the determinant factor the employer should bear in mind is the purpose that will be sought with the use of this practice (see Boswell and Boudreau, 2002). Deciding the purpose of appraisal is crucial for the configuration of the practice, since it determines its particular dimensions. Although performance appraisal may serve a wide variety of objectives, these are commonly grouped into two main categories: administrative and developmental. In what follows, we briefly describe the two types of appraisal systems and depict how the practice should be designed in order to accomplish each objective. It is worth noting that a particular system of performance appraisal could pursue both administrative and developmental objectives. However, organizations tend to give priority to a specific type of appraisal (see Boswell and Boudreau, 2002). 
Regarding the first category, establishments may adopt performance appraisal in order to administer compensation decisions, such as pay rises or variable pay systems. This type of performance appraisal could also be used to support other administrative decisions, such as the retention of workers or the adoption of disciplinary actions, among other things (see Cambon and Steiner, 2015). The results of performance appraisal are used mainly to make comparisons between workers (see Cleveland et al., 1989). On the contrary, the second category, developmental performance appraisal, is aimed at identifying training needs, evaluating training results, providing feedback to workers and guiding their development according to the results of evaluation. It focuses on the performance of each individual over time instead of making comparisons between individuals.

An administrative system should focus on the use of objective and quantitative measures such as the number of pieces produced or the value of sales. These measures are directly observed by the appraiser and the worker, which may simplify evaluation through a standardisation of processes (see Prendergast, 1999). Hence, the use of objective and quantitative measures eases comparisons between workers in order to take, for example, job assignment or retention decisions. Performance appraisal will mainly consider objectives and goals, and will give less importance to effort or behaviour. In other words, administrative purposes are related to the use of a resultsbased or an outcome-based performance appraisal (see Delery and Doty, 1996). This type of performance appraisal puts the emphasis on measuring results and outcomes, and tends to neglect those indicators that are more difficult to quantify (see Lam and Schaubroeck, 1999). Hence, aspects such as the commitment to the company, or the development of skills, are less likely to be included in the system. 
Regarding the performance appraisal results, and as we have already commented, they will be used to determine pay as well as other administrative decisions. When designing a system of appraisal, the issue of who will perform the evaluation is also a key concern (see Levy and Williams, 2004). This person is frequently an employee's immediate superior (see Murphy and Cleveland, 1995). We expect that an administrative system of appraisal relies on this figure to carry out the process, since there are not particular needs that require supervisors with specific skills. Finally, another significant feature of performance appraisal is the frequency of assessment (see Levy and Williams, 2004). The specific aim of the evaluation process may influence its timing (see Chiang and Birtch, 2010). Most administrative decisions based on the appraisal results are taken yearly. This is the case of pay decisions, among other administrative arrangements.

When pursuing a developmental objective, the supervisor needs to assess worker's performance in a comprehensive way, paying attention to various aspects of the job. Consequently, performance appraisal will take into account subjective and qualitative performance measures based on the evaluator's judgements (see Baker et al., 1994). This exhaustive evaluation might be more difficult if only objective measures of performance are used (see Prendergast, 1999). On the contrary, subjective evaluation allows a comprehensive measurement of individual performance that includes varied aspects, ranging from collaboration with other employees to the relationship with clients (see Jirjahn and Poutsma, 2013). Performance appraisal aimed at developing human capital will not focus on measuring outcomes. On the contrary, it will take into account the actions and behaviours that lead to outcomes, such as the level of effort put into the job. Hence, the developmental purpose will be linked to the use of a behaviour-based performance appraisal (see Delery and Doty, 1996). 
Evaluation results will be used to determine training needs, identify strengths and weaknesses and, more generally, to develop human capital. Regarding frequency, evaluations whose objective is to develop human capital are expected to be more frequent than those aimed at taking administrative decisions. Finally, and concerning the person who evaluates performance, a supervisor that is better qualified than the immediate superior may perform the appraisal when the evaluation process is complex or when specific appraisal needs arise (see Boswell and Boudreau, 2002). Consequently, a manager at a higher level or a HRM professional, among other positions, might be better suited to rate performance when evaluations pursue a developmental goal. It is also possible that developmental appraisal requires evaluation from different sources, since it is aimed at rating various attributes of a worker's performance (see Bohlander and Snell, 2009).

\section{The link between competitive strategy, performance appraisal and firm performance}

In this section, we formulate a set of hypotheses concerning the relationship between the competitive strategy, the design of performance appraisal and the firm's performance. On the one hand, the strategic human resource management literature points to a congruence between strategy and HRM practices (see Delery and Doty, 1996). On the other hand, the contingency approach to HRM posits that the business strategy is a factor that moderates the relationship between performance appraisal and firm performance (see Youndt et al., 1996).

In order to link business strategy with type of performance appraisal and firm performance, we resort to the well-known classification of business strategies made by 
Porter (1980) (see Camps and Luna-Arocas, 2009; Sanz-Valle et al., 2011; Samnani and Singh, 2013; Wood et al., 2015; among others). This classification differentiates between those organisations competing on costs and those that focus on differentiation. Differentiation from competitors could be obtained from different sources. One of these sources is quality, another one is innovation. From the examination of the main traits of these competitive strategies, we infer that each one implies a particular design of performance appraisal.

First, a cost strategy focuses on a reduction of costs through improvements in production efficiency (see Takeuchi, 2009). This might be achieved, for example, by pursuing economies of scale or by adopting new and more efficient technologies or production processes. It should be carried out through the implementation of simple and narrowly-defined job tasks. Employees will focus on results, particularly short-term output, trying to achieve high productivity levels in the tasks they perform (see Portales, 2001). In this context, the use of sophisticated HRM practices, that involve exhaustive selection, specific training, etc., will only have a limited impact on performance (see Youndt et al., 1996). Employees are able to learn how to perform their tasks by doing and repeating them, due to their simplicity. In light of these characteristics, it can be concluded that a cost strategy would ideally be aligned with standardised HRM systems that pursue administrative more than developmental purposes. Some relevant aspects of the HRM configuration are low levels of involvement and autonomy of workers. This strategy is based on workers' control more than on their ability or commitment to the firm (see Panayotopoulou et al., 2003; or Neal et al., 2005). Consequently, it should imply intensive monitoring of workers. On the other hand, there is low investment in training and skill-acquisition activities (see Arthur, 1992). 
Regarding the design of performance appraisal, it has been suggested that cost strategies should be accompanied by short-term results-oriented appraisal systems (see Takeuchi, 2009). When employers have low levels of autonomy and involvement, the use of performance appraisal aimed at developing their ability will have a small effect on performance. On the contrary, this strategy fits better with an administrative system of appraisal that focuses on monitoring and controlling workers' performance. On the other hand, the development of human capital is not a priority in this type of organizations. This argument is supported by the results obtained in Youndt et al. (1996). In particular, the authors find that the interaction between a cost strategy and the adoption of an administrative HRM system, which includes results-based performance appraisal, increases employee productivity.

Hypothesis 1a: Firms that focus on a cost strategy will implement an administrative system of performance appraisal.

Hypothesis 1b: There will be a positive interaction effect between the focus on a cost strategy and administrative performance appraisal on firm performance.

Second, a quality strategy focuses on improving products and services and on obtaining a competitive strategy through quality enhancement (see Takeuchi, 2009). The consolidation of a good reputation and brand image among clients is crucial to succeed. The adoption of such strategy has relevant implications in the scope of HRM (see Schuler and Jackson, 1987). High quality is mainly achieved through people, since the ideas needed to improve products and services come from workers. Hence, it is required that they are committed to continuous improvement. Employees need to be prepared to assume changes in their job requirements and work processes. In other words, they need 
to be flexible and committed to the organization (see Schuler and Jackson, 1987). As Youndt et al. (1996) point out, in order to achieve flexibility, a continuous development of human resources is crucial. Furthermore, and to guarantee involvement with the firm, employees should be given high levels of autonomy, responsibility and decision making. Finally, a focus on the long-run outcomes and stable career paths are also relevant aspects for a high quality firm (see Portales, 2001).

In light of these features, the implementation of a quality strategy might benefit from the use of a development-oriented performance appraisal. As Ghorpade et al. (1995) describe, "a company that seeks to pursue quality over an extended period of time would make the development of the individual a primary concern of the appraisal activity". Through this type of appraisal, the organization can accomplish diverse functions related to human capital development and commitment. Hence, performance appraisal can be used to identify training needs, evaluate training results, provide feedback to workers and guide the process of skill development required to succeed in enhancing the quality of products and services (see Youndt el al., 1996). Regarding performance measurement, when the firm is concerned with quality, using objective and quantitative indicators of performance might not be the best strategy to follow. The use of such indicators could encourage workers to disregard other aspects of their work, such as quality. Ghorpade et al. (1995) point out that performance appraisal should focus on behavior, although they acknowledge output can also be a useful performance indicator in certain circumstances.

Hypothesis 2a: Firms that focus on a quality strategy will implement a developmental system of performance appraisal. 
Hypothesis 2b: There will be a positive interaction effect between the focus on a quality strategy and developmental performance appraisal on firm performance.

Finally, concerning an innovation strategy, its main objective is to develop new products or services that are different from those offered by other firms (see Cooke and Sani, 2010). Furthermore, they compete through a high speed of product delivery to the market in which they operate. In order to achieve these objectives, they require flexible and fast-response production systems (see Portales, 2001). According to Schuler and Jackson (1987), those organizations pursuing innovation are characterised by a focus on long-term goals and high levels of teamwork and cooperation, so that the development of new ideas is feasible. Since workers may need to change production techniques quickly, a successful implementation of innovation strategies demands careful selection processes and concern with skill development (see Youndt et al., 1996). Workers' retention and career development are also important aspects an innovation firm should consider. Similarly to a quality-focused strategy, the pursuit of innovation implies low levels of workers' control by the employer and a higher emphasis on autonomy, since creative behaviour is needed. Experimentation and risk assumption are implied, and this might be contemplated in the compensation system. Hence, in order to encourage the personal initiative that leads to the development of innovative products, firms could use variable components of pay (see Schuler and Jackson, 1987).

Overall, we can extract the following conclusions regarding the focus on innovation and performance appraisal. Firstly, the practice should be aimed at selecting highly skilled individuals and fostering skill development. In addition, performance appraisal should be designed with the aim of minimizing workers' control and maximizing human capital development. It will allow employees to work autonomously 
and exploit their creative talent. Performance appraisal should take into account and value interdependencies between workers and cooperative behaviour. Consequently, performance indicators will be broad enough to consider these issues. Subjective measures of performance as well as indicators that account for behaviour and not only results fit better with this type of appraisal. Ittner and Larcker (2002) argue that innovation firms will benefit from performance measures related to employees' actions, such as new product development. Finally, the practice should evaluate long-term performance, since the development of new products and services requires time.

Hypothesis 3a: Firms that focus on an innovation strategy will implement a developmental system of performance appraisal.

Hypothesis 3b: There will be a positive interaction effect between the focus on an innovation strategy and developmental performance appraisal on firm performance.

\section{Methods}

1. Data

The sample was drawn from the Dun and Bradstreet directory, which contains information on 250,000 Spanish firms. Only medium and large firms with more than one hundred employees in the manufacturing and services sector were considered. From the 7,499 firms meeting these criteria, 1,300 firms were randomly selected representing all major industries.

Two questionnaires were submitted to these companies. The first one was sent to the CEO requesting general information about business strategy, organizational design and performance of the company. The second questionnaire was mailed to the senior human resource manager in the firm, who was requested detailed information about 
HRM and work organization practices and other organizational arrangements being applied to core employees. These employees, as in Osterman (1994), were defined as non-managerial employees directly involved in making the product or providing the service, and are the most difficult ones to outsource since they play a key role in firm success.

The questionnaires were carefully designed through a review of salient literature. The survey items were pre-tested with eight management professors in order to assess content validity. Moreover, a pilot study was also implemented in ten firms.

Finally, 258 pairs of usable responses were obtained, that is, the response rate was $19.9 \%$. Half of them, $51.7 \%$, came from large firms (500 employees or more) and 48.3\% from medium-sized ones (more than 100 and less than 500 employees). In terms of country of origin, Spanish-owned firms accounted for $63.3 \%$ of the usable responses. The rest of the companies were mainly subsidiaries of European and multinational corporations.

\section{Measures}

Performance appraisal. The characteristics of performance appraisal in the firm were assessed through twenty items. The senior human resource manager evaluated the items in terms of agreement or disagreement on a scale from one (strongly disagree) to seven (strongly agree). The items used refer to the different dimensions of performance appraisal underlined in the section that describes the design of the practice.

The twenty items were subject to exploratory factor analysis. Six factors with eigenvalue greater than one emerged. Eigenvalues, variance explained by them and factor loadings for the varimax rotated solution are displayed on Table 1.

[ INSERT TABLE 1 ABOUT HERE] 
As can be seen, the first factor accounts for a clearly larger part of the variance of the original items than the rest of factors. Two groups of items show high loadings for this factor. The first group comprises those items that capture the use of performance appraisal for functions other than setting variable pay. The second one includes those items that reflect that performance appraisal takes into account behaviour and soft performance indicators.

In the case of the second factor, the items with the highest loadings are the use of objective and quantitative indicators, the application in the determination of variable pay and the consideration of performance. The third factor captures the use of inputs from subordinates and colleagues at the same hierarchical level in the evaluation of an employee.

The fourth factor shows high loadings from two items: performance appraisals are conducted by superiors, and the results are not submitted to employees without having been previously discussed with them. Finally, there are two final factors associated to one item each. The fifth factor is negatively related to the frequency of the appraisal, that is, it presents higher values when it does not take place very often. On the other hand, the sixth factor is related to the secrecy of the results of the evaluation.

Because of the small proportion of variance explained by some or the factors or their single-item nature, only the first two factors are considered in our analysis. In addition, the first and the second factors can be identified, respectively, with the developmental behaviour-oriented and the administrative results-oriented approaches to appraisal described in the previous sections. For these two factors, additive indices were created with those items that have factor loadings over 0.50 .

Strategy. Competitive strategy was measured using the items introduced by Govindarajan (1988) to capture Porter typology. CEOs were requested to rank their own 
firms compared to main competitors in the following dimensions: variety of products, variety of customers, number of new products launched, product quality, product price, product value, brand image, percent of sales spent on marketing and advertising expenses, and percent of sales spent on research and development. A seven-point Likert scale was used with values ranging from significantly lower to significantly higher.

These items were factor analysed, emerging two factors with eigenvalue larger than one. The factor loadings of the varimax rotated solution for the two factors are presented in Table 2. The items that show highest loadings in the first factor are associated to product and customer variety and innovation, whereas for the second factor high loadings are found for quality and brand image items. Price shows low factor loadings in both cases. From these results, two additive indices were created with items with factor loadings over 0.50 . Both are related to differentiation strategies as opposed to low cost. However, whereas the first one reflects the focus on innovation and variety, the second one is associated to quality and brand image.

\section{[INSERT TABLE 2 ABOUT HERE]}

Similar to Arthur (1994) and Guthrie et al. (2002), and following the procedures mentioned by Hair et al. (2010), the two factors were subject to hierarchical cluster analysis. This analysis determined that the optimal number of clusters was three. Then a K-means cluster analysis was performed. The first emerging group showed mean scores of 3.376 for the innovation index and 4.154 for the quality index. These scores were 4.338 and 5.997 for the second group, whereas for the last group they took values 5.927 and 4.319. Therefore, the first group of firms can be identified as those that compete based in low cost, the second one as those that focus on quality and the third one is formed by companies emphasizing innovation. 
Firm performance. In line with previous work, we use two measures of firm performance: a measure of financial accounting and a measure of productivity (see Chadwick et al., 2015). The first one is the ROE, the most frequently used accounting measure. The ROE is an indicator of the strength of a financial institution, and it represents the value of the firm to the shareholders (see Delery and Doty, 1996; Richard, 2000; Richard and Johnson, 2001; Peng, 2004; Wahrenburg et al., 2006; Blasi et al., 2016; among many others). To complement the profitability information given by the ROE, we use a measure of the sales per employee adjusted by the productivity of the sector (see Huselid, 1995; Huselid et al., 1997; Koch and MacGratch, 1996; Guthrie, 2001; Guthrie et al., 2002; Bhattacharya et al., 2005; among many others).

Control variables. The control variables used are the number of employees, the influence of unions on employees (assessed on a one -very low- to seven - very highscale), if the firms is a subsidiary of a foreign multinational company, and the sector it belongs to (manufacturing and construction, trade and hospitality, communication and transport, financial services and other services).

First, the size variable might influence the probability of using a system of performance appraisal. On the one hand, a large establishment is more likely to have formal performance appraisal because economies of scale make it less expensive per capita (see Jirjahn and Poustma, 2013). On the other hand, large firms have more hierarchical level between workers and managers, so the process of direct monitoring and workers' control becomes more complex (see Brown and Heywood, 2005; and Grund and Sliwka, 2009). In addition, large establishments more frequently own, or have access to, the technology and knowledge needed to develop formal performance appraisal systems. 
Regarding the influence of unions, it is considered that they oppose the adoption of practices that promote differences among workers and limit their bargaining power (see Jirjahn and Poustma, 2013). In particular, they might be against the introduction of performance appraisal if it implies pay differentiation among workers (see Brown and Heywood, 2005). On the contrary, other uses of performance appraisal such as those that have to do with the development of human capital would not be problematic for unions.

Multinational companies operate in dispersed locations, so there are a geographical and a cultural distance between the headquarters and the subsidiaries. Consequently, information about workers' performance in the subsidiary might be difficult and costly to obtain by the headquarters (see Roth and O'Donnell, 1996). In order to solve this problem, they can resort to the use of formal appraisal in order to determine workers' performance. Moreover, multinational companies have to coordinate across their many locations in order to achieve goal coherence and incentive alignment, so the use of performance appraisal could be spread among the different branches of the corporation.

Finally, we include sector variables in the analysis to account for differences in production technologies that may affect the process of performance appraisal. Table 3 includes the mean, standard deviation and correlation matrix of all the variables described.

\section{[INSERT TABLE 3 ABOUT HERE]}

\section{Results}

Table 4 contains robust regression results where the two performance appraisal variables are regressed on the dummy variables capturing competitive strategy along 
with the controls described in the previous section. Robust regression is used to control for the potential distortionary effect of outliers in the least squares estimators (see Rousseeuw and Leroy, 1987).

\section{[INSERT TABLE 4 ABOUT HERE]}

The first column shows that the adoption of a development-oriented performance appraisal system is higher among firms whose competitive strategy is focused on quality and brand image or innovation and product variety. Therefore, the findings clearly point to a lower incidence of this pattern of performance appraisal in low cost strategy companies. The second model, displayed in the second column, shows a similar pattern. Firms pursuing a differentiation strategy are more prone to apply a performance appraisal approach focused on administrative purposes. This happens both for strategy based in quality or innovation.

These findings partially support our hypotheses regarding the link between competitive strategy and performance appraisal. Firstly, Hypothesis $1 a$ stated that firms with a cost strategy are more likely to implement an administrative system of performance appraisal. This is rejected by our regression results. Secondly, Hypothesis $2 a$ and Hypothesis $3 a$ stated that a focus on a quality strategy and on an innovation strategy should be related with the use of developmental performance appraisal. These predictions are supported by our findings. However, the results also reveal that firms with the two differentiation strategies display a higher use of administrative appraisal than those competing on costs.

Table 5 presents the results of the three models estimated on financial performance. In the first model, only control and strategy variables are included as explanatory variables. As can be seen, the adoption of an innovation strategy displays a positive impact on the ROE compared to the focus on reducing costs. The second model 
adds the two performance appraisal factors mentioned above. As in the previous model, a significant and positive impact of innovation emerges. Finally, the third model introduces the interaction terms between strategy and performance appraisal variables, being the latter previously centered, as in MacDuffie (1995) or Takeuchi (2009).

\section{[INSERT TABLE 5 ABOUT HERE]}

The inclusion of the interaction terms increases the explained variation of the ROE $\left(\Delta R^{2}=0.063\right)$. Again, the coefficient of the innovation variable is found significant. In addition, the estimated regression reveals a negative influence on the ROE of performance appraisal methods based on human capital development. As far as the interaction effects are concerned, the results show a positive effect on the ROE of the combination of a quality strategy and developmental performance. This result supports Hypothesis $2 b$. Finally, those firms that combine a focus on innovation and administrative performance appraisal also obtain a higher ROE. The finding contradicts Hypothesis $3 b$, which predicted the existence of a positive interaction between the focus on an innovation strategy and a developmental use of performance appraisal.

It is worth looking more deeply into the effect of the different performance appraisal types and their interaction with strategy. In order to ease their interpretation, and as suggested by Aiken et al. (1991), we graph the regression lines for each of the three strategy variables. Figure 1 shows the impact of developmental appraisal on the ROE by type of strategy. As can be seen, the use of developmental performance appraisal affects negatively the dependent variable for firms competing on the basis of cost reduction. For these firms, and holding all other variables at their mean, the ROE takes value 39.90 when the use of developmental appraisal is low and 21.76 when it is high $(\beta=-3.023 ; p=0.059)$. A negative effect is also found for firms that adopt an innovation strategy. The ROE is equal to 50.13 when they use low levels of 
developmental appraisal, and 23.82 if the use of developmental appraisal is high $(\beta=-$ 4.385; $\mathrm{p}=0.020)$. On the contrary, when the focus is set on quality, the ROE increases with the intensity of developmental appraisal. For these firms, the ROE values range from 11.01 to $36.37(\beta=4.222 ; \mathrm{p}=0.003)$.

\section{[INSERT FIGURE 1 ABOUT HERE]}

Figure 2 illustrates the interaction effects between administrative performance appraisal and strategy on the ROE. The first result that catches the attention is the null effect of administrative appraisal for cost-based firms. This effect is also insignificant in the case of quality firms. However, it can be noticed that the adoption of an administrative approach to performance appraisal exerts a positive effect on the ROE when combined with an innovation strategy. In particular, the dependent variable takes value 15.03 when the use of administrative appraisal is low, and value 40.21 when the use of administrative appraisal is high $(\beta=4.196 ; \mathrm{p}=0.011)$.

\section{[INSERT FIGURE 2 ABOUT HERE]}

In Table 6, we estimate three models with the same sets of regressors included in Table 5, but we consider an alternative measure of firm performance. This measure represents the sales per employee of the firm adjusted by the productivity level of the industrial sector. Regarding the effects of the interaction factors, we observe a positive impact of the combination between a quality strategy and a developmental use of performance appraisal on firm performance. In addition, the use of a quality strategy jointly with an administrative-oriented performance appraisal affects negatively the productivity of the firm. No significant effects are found for the interaction terms that involve an innovation strategy.

[INSERT TABLE 6 ABOUT HERE] 
To conclude the analysis, we graph the effects of the different performance appraisal types on the sales per employee, disaggregated by strategy. Looking at Figure 3 , a positive interaction effect between a quality strategy and a developmental use of performance appraisal is clearly seen. The dependent variable takes value -30.10 when the use of developmental appraisal is low, and value 7.94 when the use of administrative appraisal is high $(\beta=4.187 ; \mathrm{p}=0.000)$. On the contrary, neither the cost strategy nor the innovation strategy seem to moderate the relationship between the dependent and the explanatory variable.

\section{[INSERT FIGURE 3 ABOUT HERE]}

Figure 4 shows how the intensity of administrative appraisal decreases the sales per employee for quality firms. Clearly, these firms obtain better results if they keep the use of administrative appraisal at low levels, all else equal $(\beta=-2.031 ; p=0.034)$. In particular, the sales per employee are 3.73 when the use of administrative appraisal is low, and it becomes negative and equal to -8.46 when it is high. On the contrary, firms that adopt cost strategies benefit from the use of administrative performance appraisal, obtaining higher sales per employee as the intensity of the practice increases. For these firms, the values of the dependent variable range from -10.18 to $2.78(\beta=2.159 ; \mathrm{p}=$ 0.098). Finally, results show a null effect of administrative appraisal for cost-based firms.

\section{[INSERT FIGURE 4 ABOUT HERE]}

\section{Conclusions}

In this study, we have analyzed the relationship between the design of performance appraisal and competitive strategy, as well as the impact of such relationship on firm performance. The relevance of our work lies in the idea that, in 
order to maximize the benefits of the practice, the configuration of performance appraisal should fit the strategy pursued by the organization. The strategic HRM literature has emphasized the importance of the alignment between HRM systems and competitive strategy. Work on the topic is abundant but, to our knowledge, we are the first to analyze how the specific design of performance appraisal matches competitive strategy, and how this match affects firm performance. The lack of studies addressing this link is worrying, given the outstanding role of performance appraisal as a channel to communicate strategic objectives to workers (see Baron and Kreps, 1999) and as a method to evaluate the strategic potential of workers.

In order to advance knowledge on this topic, we have performed robust regression estimations of performance appraisal variables on explanatory variables capturing competitive strategy. The results reveal a positive connection between differentiation strategies and the use of both developmental and administrative approaches to performance appraisal, compared to the focus on cost reduction. This finding contrasts with our previous expectations, as well as those of other authors, that a cost strategy should be aligned with a use of performance appraisal focused on the administration of rewards, and based on results and outcomes. A tentative explanation for this result is that firms with differentiation strategies make more use of formal performance appraisal. On the contrary, firms competing on the basis of costs monitor their workers informally and do not implement formal systems of evaluation.

Although the theoretical arguments presented in this paper recommend the use of results-based performance appraisal when implementing a cost strategy, these arguments do not seem to guide the behavior of the sampled firms. The costs of implementing sophisticated HRM practices and the objective of cost reduction may prevent these firms from adopting formal performance appraisal of any nature 
whatsoever. Results from previous studies suggest that this is a plausible interpretation. For example, Sanz-Valle et al. (1999) find that firms with cost strategies use performance appraisal less frequently than those with differentiation strategies. In addition, the former firms spend less on training, make a lower use of incentive payment, and do not encourage the participation and involvement of workers. Overall, their findings show a lower incidence of HRM practices in those organizations that focus on cost reduction compared with quality and innovation strategies. In line with this idea, Guthrie et al. (2002) observe that the adoption of high involvement work practices is more beneficial for firms pursuing a differentiation strategy than for those competing on the basis of costs.

We also examine how the combination between strategies and systems of appraisal affects firm performance. With this analysis, we want to get back on track in the study of performance appraisal and determine when it generates performance improvements. Research on the topic has frequently neglected the practical implications of the adoption of performance appraisal and forgotten the relevance of its impact on firm performance (see DeNisi and Pritchard, 2006). In this work, we directly focus on the relationship between the design of performance appraisal and firm performance. In addition, and in contrast to previous work on the impact of HRM on performance, we take into account the particular design of the practice and not only if a system of performance appraisal is adopted or not by the organization.

Our results show that firms competing in quality and using developmental performance appraisal enjoy higher ROE and productivity. On the other hand, those firms that combine a focus on innovation with administrative performance appraisal also obtain a higher ROE. Hence, our study points to the combinations qualitydevelopmental appraisal and innovation-administrative appraisal as the optimal in terms 
of firm performance. Finally, when the priority is to compete on the basis of cost reduction, the use of administrative appraisal increases the sales per employee.

An unexpected result of this study is the positive effect on the ROE of the interaction between an innovation strategy and an administrative system of performance appraisal. This result could be related to the following idea. One of the items with a high load in our innovation variable refers to the fact that the results of performance appraisal are used to determine variable pay. Another one is the consideration of performance (objectives and goals) in appraisal. In our theoretical section, we have mentioned that variable components of pay are useful to encourage the personal initiative that leads to the development of innovative products, incorporating performance into the workers' retribution package. In this line of thought, Gomez-Mejia and Balkin (1992) show the importance of linking strategy with compensation systems. In particular, and regarding innovation firms, the authors consider that these firms could benefit from compensation practices that include an extensive use of incentive pay. Furthermore, innovation strategies require flexible and fast-response production systems. Variable pay systems enable flexibility within the firm's reward system, making it easier to adapt to changing circumstances as required. The pursuit of innovation also implies a high emphasis on workers' autonomy, since creative behaviour is needed. As suggested by Prendergast (2000), autonomous activities are more likely to require high powered incentives.

In line with the results of our paper, Miles and Snow (1987) suggested that firms with prospector strategies (meaning that they are highly innovative) would benefit from putting the emphasis on results-oriented performance appraisal. Delery and Doty (1996) share this idea. The authors argue that, when organizations constantly change their products and markets, they should rely on results-based performance appraisal. Delery 
and Doty (1996) explain how the practice provides the flexibility needed to successfully implement and innovation strategy. Their empirical analysis provides evidence of a positive interaction effect on the ROE of the prospector strategy and the use of a resultsoriented appraisal.

A strength of this study is that it allows a comparison between the theoretical prescriptions linking competitive strategies and appraisal, what firms actually do, and the impact of their decisions on firm performance. Hence, although the firms that compete on differentiation are more prone to adopt both developmental and administrative performance appraisals, this does not mean their decisions have a positive impact on performance. In fact, as we have just described, certain combinations of strategy and type of appraisal affect negatively financial performance or productivity. For example, a strategy of cost reduction leads to a lower use of administrative appraisal compared to quality firms. However, this type of appraisal reduces the sales per worker in quality firms, and it increases the sales per employee in cost firms.

From these results, we can derive some implications for management practice. First, our analysis confirms that organizations can improve their results if they align the design of performance appraisal with their strategical objectives. Furthermore, we provide evidence of what are the performance-enhancing combinations of the two variables. For firms competing on the basis of cost reduction or innovation, the optimal configuration of performance appraisal is the one that focuses on its administrative purpose. On the contrary, for firms competing on quality, the optimal configuration of performance appraisal is the one based on the development of human capital. Despite the recommendations of the contingency approach to HRM, firms do not always match their HRM practices with strategy. Hence, there is still room for improving the management of human resource systems. 
This work is subject to the usual limitations related to the use of cross-sectional data, since causality relationships cannot be proved. Future research should look at the link between performance appraisal, strategy, and performance over time to examine with precision the causal relationship among them, and to rule out the flaws of oneperiod data sets. It is worth noting that our study has been constructed using information from two sources. The CEO of the firm provided information about strategy, organizational design and performance, whereas the senior human resource manager gave information on HRM and work organization. Consequently, we have limited the common source bias of surveys with a single respondent. Our work could be extended to examine the relationship between the design of other HRM practices, competitive strategy and firm performance. As we mentioned in the Introduction, existent studies commonly consider particular HRM practices as elements of a HRM system that might be related to strategy and/or performance. However, and given that many HRM practices are multidimensional, it is worth looking at their specific configuration. 


\section{Notes}

1. The response rate of the survey is similar to that obtained in other surveys that explore HRM practices, strategy and performance (see for example Delery and Doty, 1996; Becker and Huselid, 1998; or Guthrie, 2001). 


\section{Acknowledgements}

The authors would like to thank IESE Business School for allowing us to use their surveys on business strategy and human resource management. Alberto Bayo-Moriones acknowledges financial support from the Ministerio de Educacion y Ciencia (project ECO2013-48496-C4-2-R). Jose Enrique Galdon-Sanchez and Sara Martinez-deMorentin also acknowledge financial support from the Ministerio de Educacion y Ciencia (project ECO2015-64330-P). 


\section{References}

Aiken, L. S., West, S. G., \& Reno, R. R. (1991). Multiple regression: Testing and interpreting interactions. Newbury Park, CA: Sage.

Arthur, J. B. (1992). The link between business strategy and industrial relations systems in American steel minimills. Industrial and Labor Relations Review, 45(3), 488506.

Arthur, J. B. (1994). Effects of human resource systems on manufacturing performance and turnover. Academy of Management Journal, 37(3), 670-687.

Baker, G., Gibbons, R., \& Murphy, K. J. (1994). Subjective performance measures in optimal incentive contracts. The Quarterly Journal of Economics, 109(4), 11251156.

Baron, J. N., \& Kreps, D. M. (1999). Strategic human resources: Frameworks for general managers. New York: Wiley.

Becker, B. E., \& Huselid, M. A. (1998). High performance work systems and firm performance: A synthesis of research and managerial implications. Research in Personnel and Human Resource Management, 16, 53-101.

Bhattacharya, M., Gibson, D. E., \& Doty. D. H. (2005). The effects of flexibility in employee skills, employee behaviors, and human resource practices on firm performance. Journal of Management, 31(4), 622-640.

Blasi, J., Freeman, R., \& Kruse, D. (2016). Do broad-based employee ownership, profit sharing and stock options help the best firms do even better? British Journal of Industrial Relations, 54(1), 55-82.

Bohlander, G., \& Snell, S. (2009). Managing Human Resources. South Western: Thompson. 
Boswell, W. R., \& Boudreau, J. W. (2002). Separating the developmental and evaluative performance appraisal uses. Journal of Business and Psychology, 16(3), 391-412.

Brown, M., \& Heywood, J. S. (2005). Performance appraisal systems: determinants and change. British Journal of Industrial Relations, 43(4), 659-679.

Cambon, L., \& Steiner, D. D. (2015). When rating format induces different rating processes: The effects of descriptive and evaluative rating modes on discriminability and accuracy. Journal of Business and Psychology, 30(4), 795812.

Chadwick, C., Super, J. F., \& Kwon, K. (2015). Resource orchestration in practice: CEO emphasis on SHRM, commitment-based HR systems, and firm performance. Strategic Management Journal, 36(3), 360-376.

Chiang, F. FT., \& Birtch, T. A. (2010). Appraising performance across borders: An empirical examination of the purposes and practices of performance appraisal in a multi-country context. Journal of Management Studies, 47(7), 1365-1393.

Cleveland, J. N., Murphy, K. R., \& Williams, R. E. (1989). Multiple uses of performance appraisal: Prevalence and correlates. Journal of applied psychology, 74(1), 130-135.

Cooke, F. L., \& Saini, D. S.( 2010). (How) does the HR strategy support an innovation oriented business strategy? An investigation of institutional context and organizational practices in Indian firms. Human Resource Management, 49(3), $377-400$. 
Delery, J. E., \& Doty, D. H. (1996). Modes of theorizing in strategic human resource management: Tests of universalistic, contingency, and configurational performance predictions. Academy of management Journal, 39(4), 802-835.

DeNisi, A. S., \&. Pritchard, R. D. (2006). Performance appraisal, performance management and improving individual performance: A motivational framework. Management and Organization Review, 2(2), 253-277.

Ding, D. Z., \& Akhtar, S. (2001). The organizational choice of human resource management practices: a study of Chinese enterprises in three cities in the PRC. International Journal of Human Resource Management, 12(6), 946-964.

Ghorpade, J., Chen, M. M., \& Caggiano, J. (1995). Creating quality-driven performance appraisal systems [and executive commentary]. Academy of Management Executive, 9(1), 32-41.

Gomez-Mejia, L.R. \& Balkin, D.B. (1992). Compensation, organizational strategy, and firm performance. Cincinnati, OH: South-Western.

Govindarajan, V. (1988). A contingency approach to strategy implementation at the business-unit level: integrating administrative mechanisms with strategy. Academy of management Journal, 31(4), 828-853.

Grund, C., \& Sliwka, D. (2009). The anatomy of performance appraisals in Germany. The International Journal of Human Resource Management, 20(10), 2049-2065.

Guthrie, J. P. (2001). High-involvement work practices, turnover, and productivity: Evidence from New Zealand. Academy of Management Journal, 44(1), 180-90.

Guthrie, J. P., Spell, C. S., \& Nyamori, R. O. (2002). Correlates and consequences of high involvement work practices: the role of competitive strategy. International journal of human resource management, 13(1), 183-197. 
Hair, J. F., Anderson, R., Tatham, R. \& Black, W. (2010). Multivariate data analysis. Upper Saddle River, NJ: Pearson Prentice Hall.

Huselid, M. A. (1995). The impact of human resource management practices on turnover, productivity and corporate financial performance. Academy of Management Journal, 38(3), 635-672.

Huselid, M. A., Jackson, S. E., \& Schuler, R. S. (1997). Technical and strategic human resources management effectiveness as determinants of firm performance. Academy of Management Journal, 40(1), 171-188.

Ittner, C. D., \& Larcker, D. F. (2002). Determinants of performance measure choices in worker incentive plans. Journal of Labor Economics, 20(S2), S58-S90.

Jirjahn, U., \& Poutsma, E. (2013). The use of performance appraisal systems: evidence from dutch establishment data. Industrial Relations: A Journal of Economy and Society, 52(4), 801-828.

Koch, M. J., \& McGrath, R. G. (1996). Improving labor productivity: Human resource management policies do matter. Strategic Management Journal, 17(5), 335-354.

Kuvaas, B., Buch, R., \& Dysvik, A. (2014). Performance management: Perceiving goals as invariable and implications for perceived job autonomy and work performance. Human Resource Management, 55(3), 401-412.

Lam, S. SK, \& Schaubroeck, J. (1999). Total quality management and performance appraisal: An experimental study of process versus results and group versus individual approaches. Journal of Organizational Behavior, 20(4), 445-457.

Levy, P. E., \& Williams, J. R. (2004). The social context of performance appraisal: A review and framework for the future. Journal of Management, 30(6), 881-905. 
Macduffie, J. P. (1995). Human resource bundles and manufacturing performance: organizational logic and flexible production systems in the world auto industry. Industrial and Labor Relations Review, 48(2), 197-221.

Michie, J., \& Sheehan, M. (2005). Business strategy, human resources, labour market flexibility and competitive advantage. The International Journal of Human Resource Management, 16(3), 445-464.

Murphy, K. R., \& Cleveland, J. N. (1995). Understanding Performance Appraisal: Social, Organisational, and Goal-Based Perspectives. Thousand Oaks CA: Sage.

Neal, A., West, M. A., \& Patterson, M. G. (2005). Do organizational climate and competitive strategy moderate the relationship between human resource management and productivity? Journal of Management, 31(4), 492-512.

Ortega, M. J. R. (2010). Competitive strategies and firm performance: Technological capabilities' moderating roles. Journal of Business Research, 63(12), 1273-1281.

Osterman, P. (1994). How common is workplace transformation and who adopts it? Industrial \& Labor Relations Review, 47(2), 173-188.

Panayotopoulou, L., Bourantas, D., \& Papalexandris, N. (2003). Strategic human resource management and its effects on firm performance: an implementation of the competing values framework. The International Journal of Human Resource Management, 14(4), 680-699.

Peng, M. W. (2004). Outside directors and firm performance during institutional transitions. Strategic Management Journal, 25(5), 453-471.

Portales, C. (2001). Business strategy and employment systems in Spain: an empirical analysis. In J. Gual \& J. E. Ricart (Eds.), Strategy, Organization and the Changing Nature of Work (pp.124-168). Northampton, MA: Edward Elgar. 
Porter, M. E. (1980). Competitive strategy: Techniques for analyzing industries and competitors. Cambridge: Harvard Business School.

Prendergast, C. (1999). The provision of incentives in firms. Journal of Economic Literature, 37(1), 7-63.

Richard, O. C. (2000). Racial diversity, business strategy, and firm performance: A resource-based view. Academy of Management Journal, 43(2), 164-77.

Richard, O. C., \& Johnson, N. B. (2001). Strategic human resource management effectiveness and firm performance. The International Journal of Human Resource Management, 12(2), 299-310.

Roth, K., \& O'Donnell, S. (1996). Foreign subsidiary compensation strategy: An agency theory perspective. Academy of management Journal, 39(3), 678-703.

Rousseeuw, P. J., \& Leroy, A. M. (1987). Robust Regression and Outlier Detection. New York: Wiley.

Samnani, A. K., \& Singh, P. (2013). Exploring the fit perspective: an ethnographic approach. Human Resource Management, 52(1), 123-144.

Sanz-Valle, R., Sabater-Sanchez, R., \& Aragon-Sanchez, A. (1999). Human resource management and business strategy links:A empirical study. International Journal of Human Resource Management, 10(4), 655-671.

Schuler, R. S., \& Jackson, S. E. (1987). Linking competitive strategies with human resource management practices. Academy of Management Executive, 1(3), 207-19.

Snell, S. A., \& Youndt, M. A. (1995). Human resource management and firm performance: Testing a contingency model of executive controls. Journal of Management, 21(4), 711-737. 
Takeuchi, N. (2009). How Japanese manufacturing firms align their human resource policies with business strategies: testing a contingency performance prediction in a Japanese context. The International Journal of Human Resource Management, 20(1), 34-56.

Prendergast, C. (2000). What trade-off of risk and incentives?. The American Economic Review, 90(2), 421-425.

Wahrenburg, M., Hackethal, A., Friedrich, L., \& Gellrich, T. (2006). Strategic decisions regarding the vertical integration of human resource organizations: evidence for an integrated HR model for the financial services and non-financial services industry in Germany, Austria and Switzerland. The International Journal of Human Resource Management, 17(10), 1726-1771.

Wood, S., Nolte, S., Burridge, M., Rudloff, D., \& Green, W. (2015). Dimensions and location of high-involvement management: fresh evidence from the UK Commission's 2011 Employer Skills Survey. Human Resource Management Journal, 25(2), 166-183.

Youndt, M. A., Snell, S. A., Dean, J. W., \& Lepak, D. P. (1996). Human resource management, manufacturing strategy, and firm performance. Academy of management Journal, 39(4), 836-866.

Zhang, Y. C., and Li, S. L. (2009). High performance work practices and firm performance: evidence from the pharmaceutical industry in China. The International Journal of Human Resource Management, 20(11), 2331-2348. 
Table 1. Eigenvalues, Percentage of Variance Explained and Factor Loadings of the Rotated Solution for Performance Appraisal Items

\begin{tabular}{|c|c|c|c|c|c|c|}
\hline & Factor 1 & Factor 2 & Factor 3 & Factor 4 & Factor 5 & Factor 6 \\
\hline Eigenvalue & 5.257 & 2.396 & 1.688 & 1.326 & 1.109 & 1.048 \\
\hline$\%$ of variance & 25.033 & 11.411 & 8.037 & 6.314 & 5.280 & 4.989 \\
\hline Cronbach's alpha & 0.880 & 0.634 & 0.734 & 0.253 & - & - \\
\hline $\begin{array}{l}\text { PA is conducted formally (through formularies, with } \\
\text { predetermined scales, etc.) }\end{array}$ & 0.162 & 0.449 & 0.216 & 0.210 & 0.437 & 0.245 \\
\hline PA is secret & 0.176 & 0.067 & -0.126 & -0.029 & 0.013 & 0.820 \\
\hline $\begin{array}{l}\text { PA results are not submitted to the employee without } \\
\text { discussion with him }\end{array}$ & -0.009 & 0.193 & -0.110 & 0.674 & 0.137 & -0.133 \\
\hline PA is conducted by the superiors & 0.080 & -0.068 & -0.050 & 0.743 & -0.072 & 0.073 \\
\hline PA is conducted by subordinates & 0.093 & 0.180 & 0.806 & -0.173 & -0.012 & -0.091 \\
\hline PA is conducted by colleagues at the same level & 0.003 & -0.005 & 0.859 & -0.043 & -0.022 & -0.058 \\
\hline PA is made through objective and quantitative indicators & 0.014 & 0.772 & 0.056 & -0.011 & -0.085 & -0.012 \\
\hline PA is made through subjective and qualitative indicators & 0.306 & -0.296 & 0.354 & 0.273 & 0.220 & 0.268 \\
\hline PA is conducted monthly & -0.039 & 0.109 & 0.053 & -0.011 & -0.847 & 0.030 \\
\hline PA results are used for variable pay & -0.075 & 0.675 & -0.028 & -0.074 & 0.015 & 0.323 \\
\hline PA results are used for job assignments decisions & 0.716 & 0.127 & 0.071 & -0.016 & -0.119 & 0.090 \\
\hline $\begin{array}{l}\text { PA results are used to determine training and development } \\
\text { needs }\end{array}$ & 0.702 & 0.086 & 0.088 & 0.016 & -0.090 & 0.237 \\
\hline PA results are used for promotion and transfer decisions & 0.716 & -0.020 & -0.003 & -0.108 & -0.194 & 0.321 \\
\hline PA takes into account performance (objectives and goals) & 0.170 & 0.752 & 0.093 & 0.173 & -0.035 & -0.190 \\
\hline PA takes into account effort & 0.659 & -0.002 & -0.170 & -0.091 & 0.316 & 0.037 \\
\hline PA takes into account behaviour & 0.802 & -0.092 & -0.037 & 0.053 & 0.087 & 0.020 \\
\hline PA takes into account commitment to the company & 0.767 & -0.044 & -0.064 & 0.017 & 0.202 & -0.132 \\
\hline PA takes into account the development of skills & 0.686 & 0.252 & 0.153 & 0.109 & 0.193 & -0.134 \\
\hline PA takes into account the development of subordinates & 0.590 & 0.122 & 0.345 & 0.153 & -0.124 & 0.060 \\
\hline PA takes into account the ability to manage people & 0.754 & -0.083 & 0.153 & 0.174 & 0.075 & 0.068 \\
\hline
\end{tabular}


Table 2. Factor Loadings of the Rotated Solution for Strategy Items

\begin{tabular}{lcc}
\hline & Factor 1 & Factor 2 \\
\hline Eigenvalue & 3.511 & 3.163 \\
\% of variance & 39.015 & 35.142 \\
Cronbach's alpha & 0.935 & 0.921 \\
\hline Variety of products & $\mathbf{0 . 9 3 8}$ & -0.039 \\
Variety of customers & $\mathbf{0 . 8 9 9}$ & -0.035 \\
Number of new products launched & $\mathbf{0 . 9 3 6}$ & -0.038 \\
Product quality & -0.026 & $\mathbf{0 . 9 3 8}$ \\
Product price & 0.143 & 0.253 \\
Product value & -0.113 & $\mathbf{0 . 8 8 8}$ \\
Brand image & -0.038 & $\mathbf{0 . 9 0 2}$ \\
Percent of sales spent on marketing and advertising expenses & -0.032 & $\mathbf{0 . 8 5 8}$ \\
Percent of sales spent on research and development & $\mathbf{0 . 8 8 3}$ & 0.095 \\
\hline
\end{tabular}


Table 3. Mean, Standard Deviation and Correlation Matrix

\begin{tabular}{|c|c|c|c|c|c|c|c|c|c|}
\hline & Mean & S.d. & 1 & 2 & 3 & 4 & 5 & 6 & 7 \\
\hline 1. Developmental Appraisal & 4.985 & 1.092 & & & & & & & \\
\hline 2. Administrative Appraisal & 5.204 & 1.265 & .092 & & & & & & \\
\hline 3. Quality strategy & 0.438 & 0.497 & .060 & .049 & & & & & \\
\hline 4. Innovation strategy & 0.279 & 0.449 & $.110 *$ & $.148 * *$ & $-.549 * * *$ & & & & \\
\hline 5. No. of employees & 6.442 & 1.141 & $.121 *$ & .018 & $.170 * * *$ & -.050 & & & \\
\hline 6. Subsidiary of foreign MNC & 0.368 & 0.483 & $.148 * *$ & $.233 * * *$ & .055 & .080 & .004 & & \\
\hline 7. Union influence & 3.217 & 1.563 & -.039 & -.032 & .012 & -.020 & $.177 * * *$ & -.039 & \\
\hline 8. Manufacturing & 0.523 & 0.500 & -.040 & -.083 & -.080 & -.075 & $-.135 * *$ & .037 & $.257 * * *$ \\
\hline 9. Trade and hospitality & 0.143 & 0.351 & -.057 & .086 & .085 & -.057 & -.041 & .032 & $-.185 * * *$ \\
\hline 10.Communication and transport & 0.066 & 0.249 & .026 & -.047 & .049 & -.096 & $.138 * *$ & .056 & -.017 \\
\hline 11. Financial services & 0.132 & 0.339 & .040 & .016 & -.067 & .090 & $.218 * * *$ & -.084 & .005 \\
\hline 12. ROE & 16.880 & 62.651 & .010 & -.031 & -.073 & .069 & $-.140 * *$ & $.129 * *$ & $-.202 * * *$ \\
\hline $\begin{array}{l}\text { 13. Sales per employee adjusted } \\
\text { by sector productivity }\end{array}$ & -2.554 & 18.914 & .032 & -.009 & $-.109 *$ & .061 & .015 & .068 & -.024 \\
\hline
\end{tabular}

$* * * \mathrm{p}<0.01, * * \mathrm{p}<0.05, * \mathrm{p}<0.10$ 


\section{Table 3. Mean, Standard Deviation and Correlation Matrix (cont.)}

\begin{tabular}{lccccc}
\hline & $\mathbf{8}$ & $\mathbf{9}$ & $\mathbf{1 0}$ & $\mathbf{1 1}$ & $\mathbf{1 2}$ \\
\hline 1. Factor 1 & & & & & \\
2. Factor 2 & & & & & \\
3. Quality strategy & & & & & \\
4. Innovation strategy & & & & & \\
5. No. of employees & & & & & \\
6. Subsidiary of foreign MNC & & & & & \\
7. Union influence & & & & & \\
8. Manufacturing & $-.429^{* * *}$ & & & & \\
9. Trade and hospitality & $-.278^{* * *}$ & $-.109^{*}$ & & & \\
10.Communication and transport & $-.408^{* * *}$ & $-.159^{* *}$ & $-.104^{*}$ & & \\
11. Financial services & $-.119^{*}$ & .067 & .019 & -.002 & \\
12. ROE & $-.116^{*}$ & .075 & -.032 & .050 & $.193^{* * *}$ \\
13. Sales per employee adjusted \\
by sector productivity & & & & & \\
$* * * \mathrm{p}<0.01, * * \mathrm{p}<0.05, * \mathrm{p}<0.10$ & & & & &
\end{tabular}


Table 4. Competitive Strategy and Type of Performance Appraisal

\begin{tabular}{lcc}
\hline & Developmental & Administrative \\
& Appraisal & Appraisal \\
\hline Constant & $4.582^{* * *}$ & $4.940^{* * *}$ \\
& $(0.404)$ & $(0.487)$ \\
No. of employees & 6.727 & 0.000 \\
(logarithm)/100 & $(0.060)$ & $(0.072)$ \\
Subsidiary of foreign MNC & $0.289 * *$ & $0.473 * * *$ \\
& $(0.133)$ & $(0.160)$ \\
Union influence & -0.045 & 0.002 \\
& $(0.043)$ & $(0.052)$ \\
Manufacturing & -0.182 & -0.275 \\
& $(0.198)$ & $(0.239)$ \\
Trade and hospitality & -0.364 & 0.070 \\
& $(0.238)$ & $(0.287)$ \\
Communication and transport & -0.214 & -0.349 \\
& $(0.304)$ & $(0.366)$ \\
Financial services & -0.032 & -0.112 \\
& $(0.251)$ & $(0.303)$ \\
\hline Quality strategy & $0.332^{* *}$ & $0.402^{* *}$ \\
Innovation strategy & $(0.156)$ & $(0.188)$ \\
& $0.457 * *$ & $0.638^{* * *}$ \\
\hline $\mathrm{F}$ & $(0.171)$ & $(0.206)$ \\
$\mathrm{R}^{2}$ & $2.301 * *$ & $2.801 * * *$ \\
\hline$* * * \mathrm{p}<0.01, * * \mathrm{p}<0.05, * \mathrm{p}<0.10$ & .077 & 0.093 \\
\hline
\end{tabular}

Standard errors in parentheses 
Table 5. Competitive Strategy, Performance Appraisal and Return on Equity

\begin{tabular}{|c|c|c|c|}
\hline & Model 1 & Model 2 & Model 3 \\
\hline Constant & $\begin{array}{c}30.502 * * * \\
(5.999)\end{array}$ & $\begin{array}{c}30.927 * * * \\
(6.132)\end{array}$ & $\begin{array}{c}29.876 \text { *** } \\
(13.089)\end{array}$ \\
\hline No. of employees (logarithm) & $\begin{array}{l}-0.952 \\
(0.886)\end{array}$ & $\begin{array}{l}-0.920 \\
(0.904)\end{array}$ & $\begin{array}{l}-1.042 \\
(0.885)\end{array}$ \\
\hline Subsidiary of foreign $M N C$ & $\begin{array}{l}6.152 * * \\
(1.974)\end{array}$ & $\begin{array}{l}5.967 * * \\
(2.068)\end{array}$ & $\begin{array}{l}5.177 * * \\
(2.032)\end{array}$ \\
\hline Union influence & $\begin{array}{l}-0.861 \\
(0.643)\end{array}$ & $\begin{array}{l}-0.930 \\
(0.654)\end{array}$ & $\begin{array}{l}-1.221 * \\
(0.639)\end{array}$ \\
\hline Manufacturing & $\begin{array}{c}-7.869 * * * \\
(2.946)\end{array}$ & $\begin{array}{c}-7.566^{* * *} \\
(3.008)\end{array}$ & $\begin{array}{l}-4.485 \\
(2.985)\end{array}$ \\
\hline Trade and hospitality & $\begin{array}{c}-2.508 \\
(3.542)\end{array}$ & $\begin{array}{l}-2.636 \\
(3.610)\end{array}$ & $\begin{array}{c}-1.272 \\
(3.540)\end{array}$ \\
\hline Communication and transport & $\begin{array}{l}-8.840 * \\
(4.513)\end{array}$ & $\begin{array}{l}-8.838^{*} \\
(4.596)\end{array}$ & $\begin{array}{l}-5.869 \\
(4.490)\end{array}$ \\
\hline Financial services & $\begin{array}{c}-8.662 * * \\
(3.735) \\
\end{array}$ & $\begin{array}{c}-8.665^{* *} \\
(3.794) \\
\end{array}$ & $\begin{array}{c}-5.797 \\
(3.791) \\
\end{array}$ \\
\hline Quality strategy & $\begin{array}{c}2.633 \\
(2.319)\end{array}$ & $\begin{array}{c}2.207 \\
(2.386)\end{array}$ & $\begin{array}{c}2.958 \\
(2.448)\end{array}$ \\
\hline Innovation strategy & $\begin{array}{c}5.525^{* *} \\
(2.537)\end{array}$ & $\begin{array}{l}4.806^{*} \\
(2.647)\end{array}$ & $\begin{array}{l}4.800^{*} \\
(2.680)\end{array}$ \\
\hline Developmental Appraisal & & $\begin{array}{c}0.028 \\
(0.903)\end{array}$ & $\begin{array}{c}-3.023^{*} \\
(1.592)\end{array}$ \\
\hline Administrative Appraisal & & $\begin{array}{c}0.758 \\
(0.794)\end{array}$ & $\begin{array}{c}0.489 \\
(1.520)\end{array}$ \\
\hline Developmental Appraisal x Quality strategy & & & $\begin{array}{c}7.246 * * * \\
(2.130)\end{array}$ \\
\hline Administrative Appraisal x Quality strategy & & & $\begin{array}{c}-0.488 \\
(1.872)\end{array}$ \\
\hline Developmental Appraisal x Innovation strategy & & & $\begin{array}{l}-1.361 \\
(2.456)\end{array}$ \\
\hline Administrative Appraisal x Innovation strategy & & & $\begin{array}{l}3.707 * \\
(2.215)\end{array}$ \\
\hline $\mathrm{F}$ & $3.848 * * *$ & $3.213^{* *}$ & $3.734 * * *$ \\
\hline $\mathrm{R}^{2}$ & 0.123 & 0.126 & 0.189 \\
\hline
\end{tabular}

Standard errors in parentheses 
Table 6. Competitive Strategy, Performance Appraisal and Sales per Employee (Adjusted by Productivity of the Sector)

\begin{tabular}{|c|c|c|c|}
\hline & Model 1 & Model 2 & Model 3 \\
\hline Constant & $\begin{array}{l}-4.567 \\
(5.282)\end{array}$ & $\begin{array}{l}-4.108 \\
(7.087)\end{array}$ & $\begin{array}{l}-6.671 \\
(5.149)\end{array}$ \\
\hline No. of employees (logarithm) & $\begin{array}{c}0.694 \\
(0.780)\end{array}$ & $\begin{array}{c}0.715 \\
(0.792)\end{array}$ & $\begin{array}{c}0.845 \\
(0.757)\end{array}$ \\
\hline Subsidiary of foreign $M N C$ & $\begin{array}{c}3.919 * * \\
(1.738)\end{array}$ & $\begin{array}{c}4.000 * * \\
(1.810)\end{array}$ & $\begin{array}{l}3.268 * \\
(1.737)\end{array}$ \\
\hline Union influence & $\begin{array}{c}0.158 \\
(0.566)\end{array}$ & $\begin{array}{c}0.162 \\
(0.572)\end{array}$ & $\begin{array}{c}0.273 \\
(0.546)\end{array}$ \\
\hline Manufacturing & $\begin{array}{c}-6.392 * * \\
(2.594)\end{array}$ & $\begin{array}{c}-6.437 * * \\
(2.633)\end{array}$ & $\begin{array}{l}-4.424^{*} \\
(2.552)\end{array}$ \\
\hline Trade and hospitality & $\begin{array}{c}-5.692^{*} \\
(3.119)\end{array}$ & $\begin{array}{l}-5.734 * \\
(3.161)\end{array}$ & $\begin{array}{l}-4.027 \\
(3.026)\end{array}$ \\
\hline Communication and transport & $\begin{array}{l}-6.279 \\
(3.974)\end{array}$ & $\begin{array}{l}-6.361 \\
(4.024)\end{array}$ & $\begin{array}{l}-4.019 \\
(3.839)\end{array}$ \\
\hline Financial services & $\begin{array}{c}-3.244 \\
(3.288) \\
\end{array}$ & $\begin{array}{l}-3.280 \\
(3.322) \\
\end{array}$ & $\begin{array}{c}-0.184 \\
(3.241) \\
\end{array}$ \\
\hline Quality strategy & $\begin{array}{l}-2.809 \\
(2.042)\end{array}$ & $\begin{array}{l}-2.774 \\
(2.089)\end{array}$ & $\begin{array}{l}-3.691^{*} \\
(2.093)\end{array}$ \\
\hline Innovation strategy & $\begin{array}{c}1.487 \\
(2.233)\end{array}$ & $\begin{array}{c}1.549 \\
(2.318)\end{array}$ & $\begin{array}{c}1.035 \\
(2.291)\end{array}$ \\
\hline Developmental Appraisal & & $\begin{array}{l}-0.025 \\
(0.791)\end{array}$ & $\begin{array}{c}-2.153 \\
(1.361)\end{array}$ \\
\hline Administrative Appraisal & & $\begin{array}{l}-0.098 \\
(0.695)\end{array}$ & $\begin{array}{l}2.159 * \\
(1.230)\end{array}$ \\
\hline Developmental Appraisal x Quality strategy & & & $\begin{array}{c}6.340 * * * \\
(1.821)\end{array}$ \\
\hline Administrative Appraisal x Quality strategy & & & $\begin{array}{c}-4.190 * * * \\
(1.600)\end{array}$ \\
\hline Developmental Appraisal x Innovation strategy & & & $\begin{array}{c}0.073 \\
(2.099)\end{array}$ \\
\hline Administrative Appraisal x Innovation strategy & & & $\begin{array}{l}-1.678 \\
(1.894)\end{array}$ \\
\hline $\mathrm{F}$ & $1.804 *$ & 1.460 & $2.992 * * *$ \\
\hline $\mathrm{R}^{2}$ & 0.062 & 0.062 & 0.157 \\
\hline
\end{tabular}

Standard errors in parentheses 
Figure 1. Effects of Developmental Appraisal on Return on Equity, by Strategy

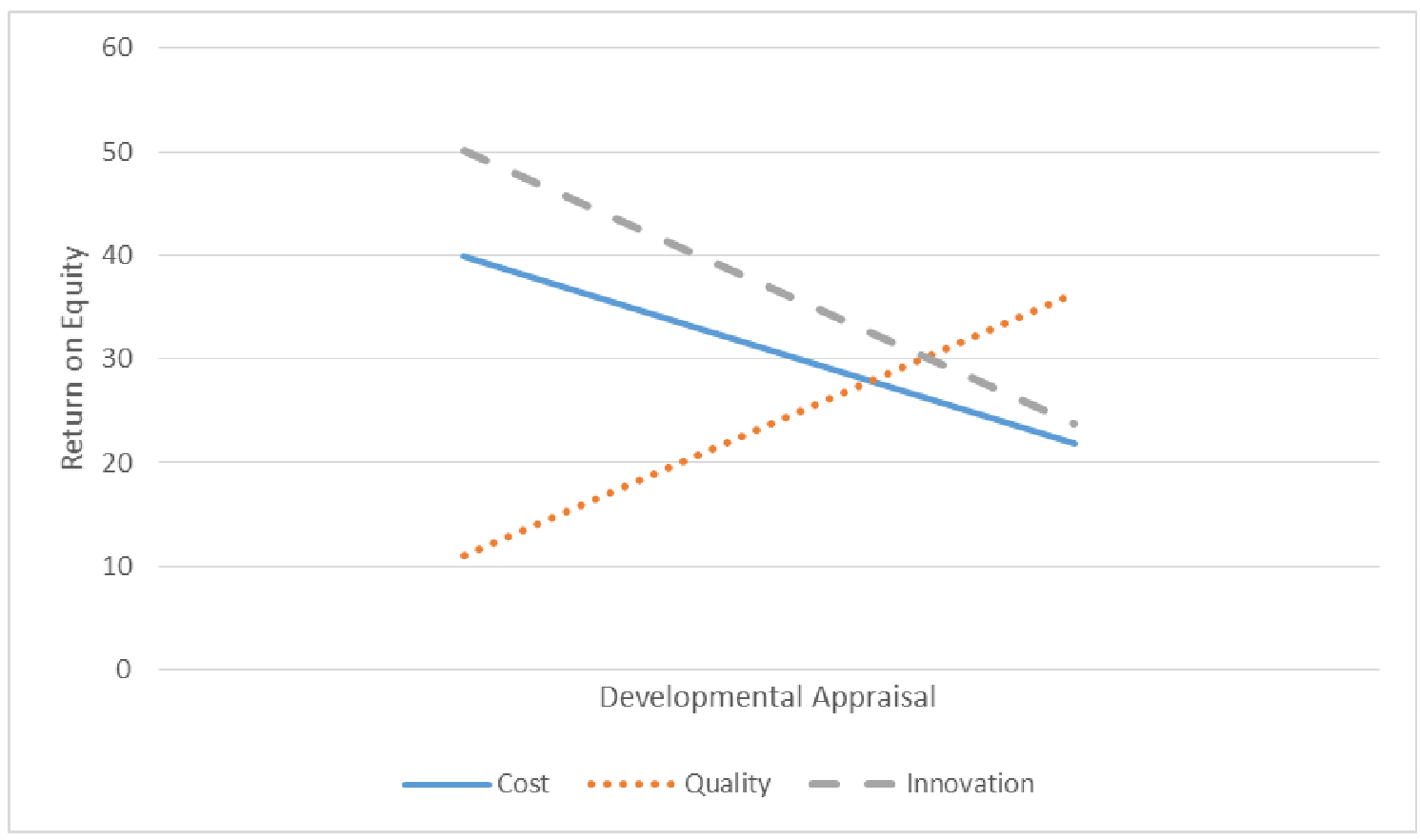

Figure 2. Effects of Administrative Appraisal on Return on Equity, by Strategy

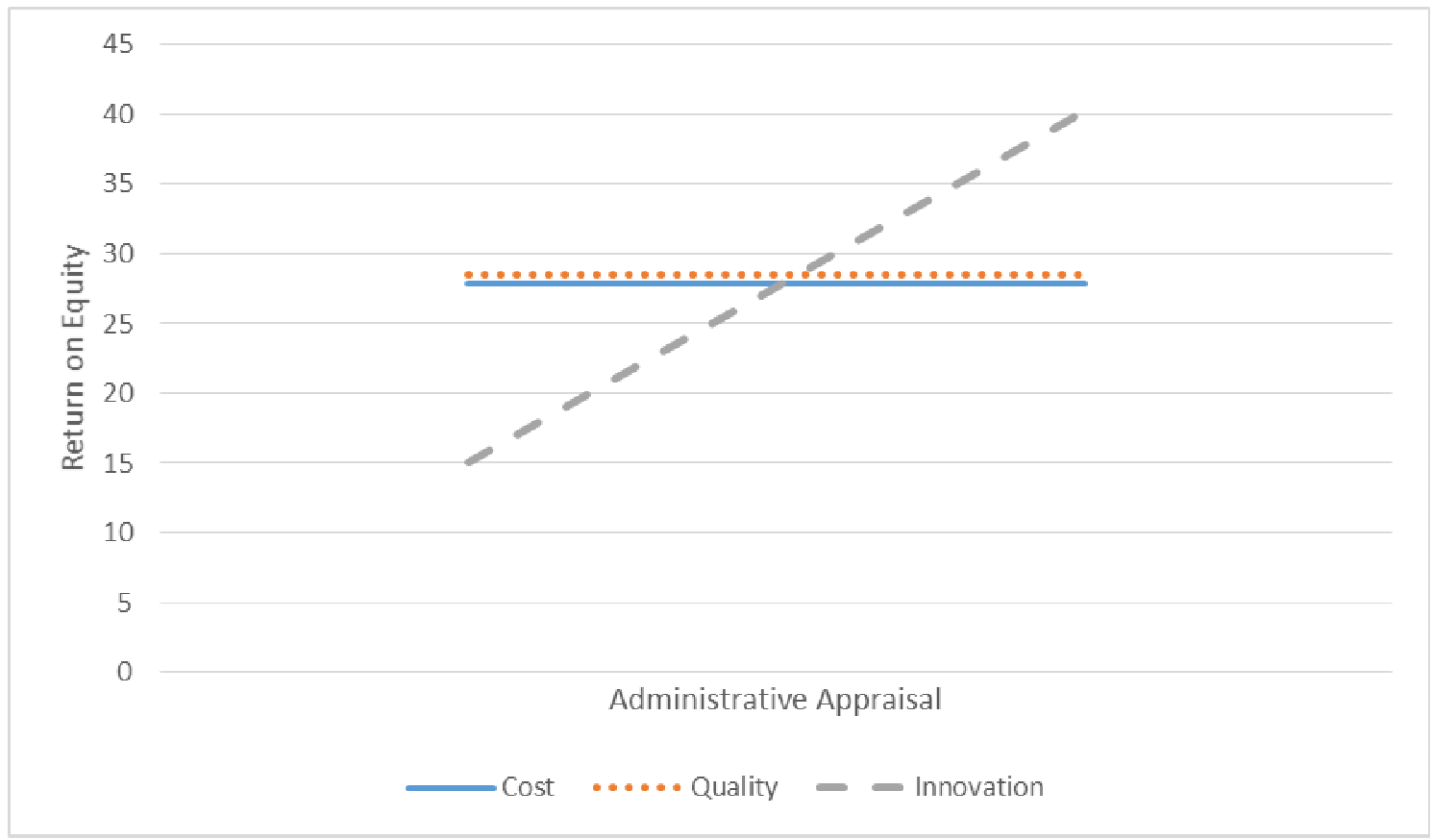


Figure 3. Effects of Developmental Appraisal on Sales per Employee adjusted by Sector Productivity, by Strategy

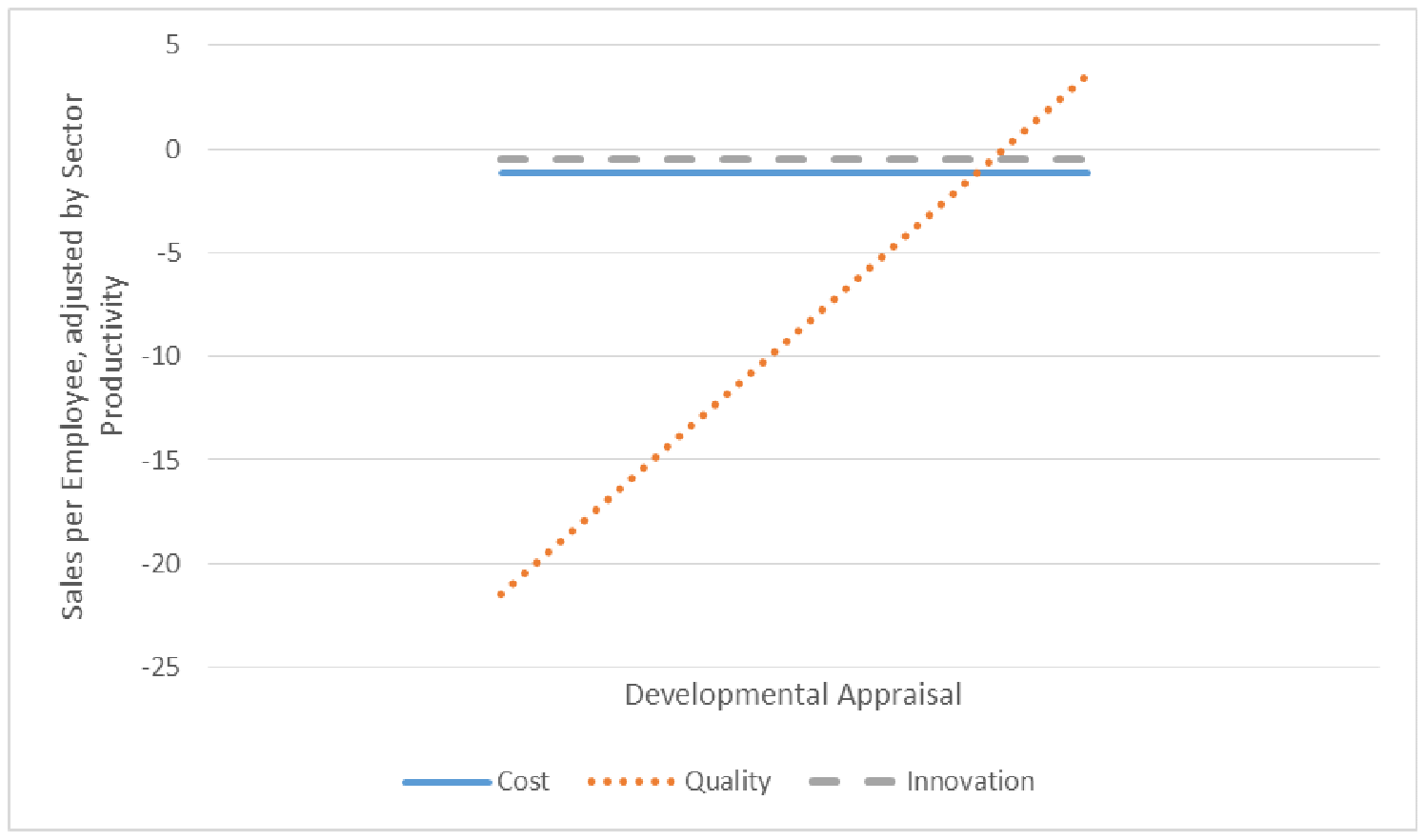

Figure 4. Effects of Administrative Appraisal on Sales per Employee adjusted by Sector Productivity, by Strategy

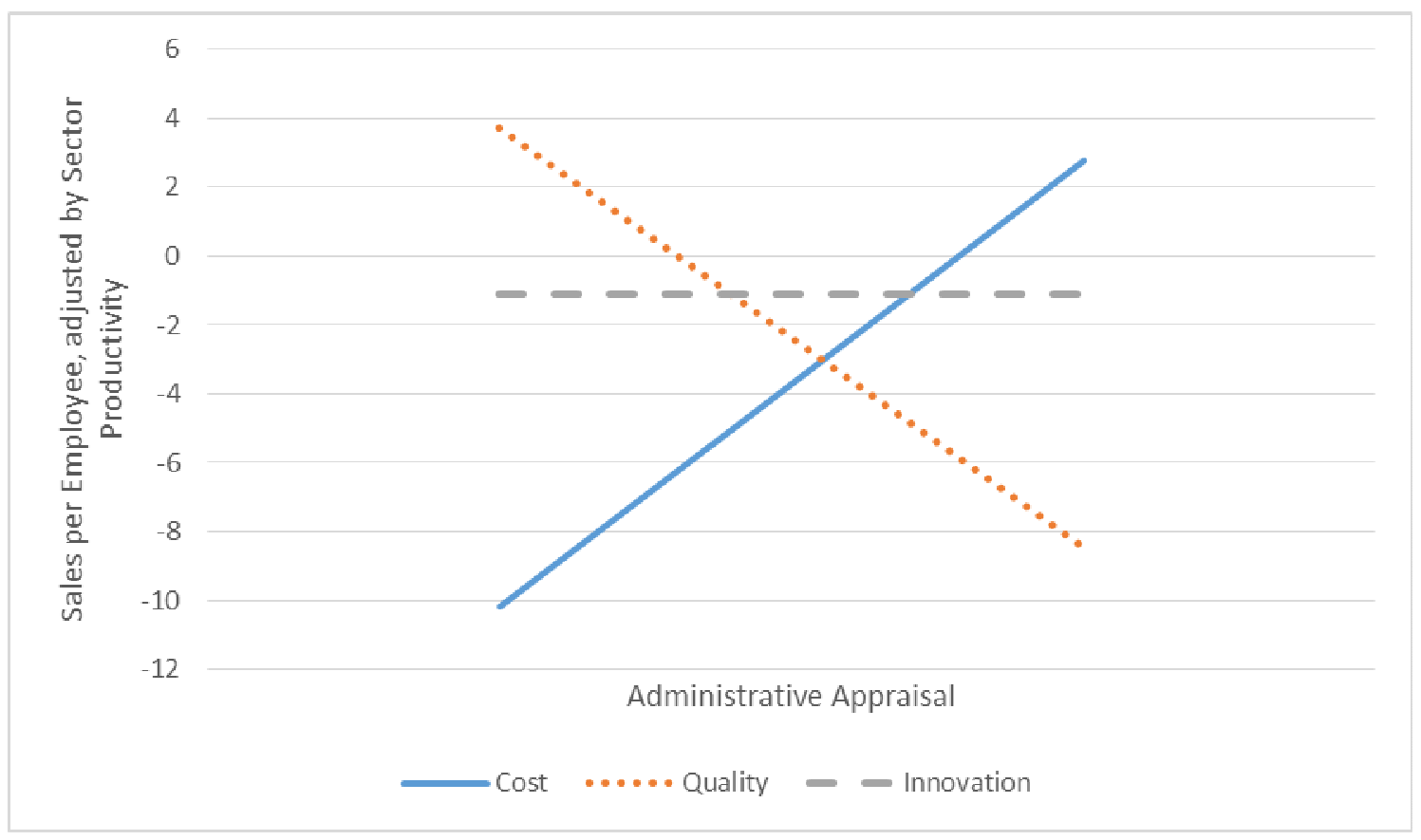

